nhóm bệnh có khác biệt, đặc biệt các thông số về tâm trương thất trái. Điều này phù hợp vì đó là các tiêu chuẩn để chẩn đoán suy tim với phân suất tống máu thất trái $\geq 50 \%$ (vốn chiếm đa số trong các đối tượng nghiên cứu).

Các thông số siêu âm của nhóm suy tim có và không có $\mathrm{HCCH}$ chỉ ghi nhận sự khác biệt về thể tích nhĩ trái nhỏ nhất và chức năng dẫn máu tống máu - chứa máu của nhĩ trái. Ngoài ra không ghi nhận khác biệt về cấu trúc, chức năng tâm thu và tâm trương thất trái. Kết quả này phù hợp với một số tác giả khác ${ }^{(6,7)}$ (nghiên cứu trên các đối tượng tương tự).

Ngoài các yếu tố đóng góp vào mô hình hồi quy tuyến tính đa biến ở trên, một số yếu tố khác được dự đoán có đóng góp lớn nhưng cuối cùng khổng đưa được vào xây dựng mô hình do không có phân phối chuẩn. Một số biến cũng không đưa vào phân tích đơn biến được do không có phân phối chuẩn.

\section{KẾT LUẦN}

5.1. Đặc điểm kích thước, chức năng nhĩ trái ở bệnh nhân suy tim phân suất tống máu thất trái $\geq 40 \%$ có và không có hội chứng chuyển hóa

- Các thông số siêu âm về thất trái, thất phải, chức năng tâm thu, chức năng tâm trương của các bệnh nhân có và không có $\mathrm{HCCH}$ tương đương nhau.

- Bệnh nhân suy tim phân suất tống máu $\geq$ $40 \%$ kèm HCCH thì chỉ số thể tích nhĩ trái tối thiểu có xu hướng lớn hơn những bệnh nhân không bi HCCH.

- Các phân suất làm rỗng nhĩ trái ở nhóm có
HCCH thấp hơn nhóm không có HCCH.

5.2. Mối liên quan giữa kích thước, chức năng nhĩ trái với một số dấu hiệu lâm sàng và cận lâm sàng đánh giá suy tim

- Chức năng dẫn máu, tống máu và chứa máu của nhĩ trái có xu hướng thấp hơn ở nhóm có phân độ NYHA trầm trọng hơn.

- Khi thất trái càng giãn và càng dày, chỉ số đường kính nhĩ trái và các chỉ số thể tích nhĩ trái có xu hướng tăng lên.

- Có mối tương quan tuyến tính nghịch biến giữa LAtEF với BMI theo phương trình: $Y=$ 0.91 . BMI + 78.91

\section{TÀI LIẸU THAM KHẢO}

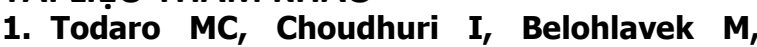
Jahangir A, Carerj S, Oreto $L$, et al. New echocardiographic techniques for evaluation of left atrial mechanics. Eur Heart J Cardiovasc Imaging. 2012;13(12):973-84.

2. Huang PL. A comprehensive definition for metabolic syndrome. Dis Model Mech. 2009;2(5-6):231-7.

3. Gupta A, Gupta V. Metabolic syndrome: what are the risks for humans? Bioscience trends. 2010;4(5):204-12.

4. Vinh PN. Khuyến cáo của hôi Tim mach Quốc gia Việt Nam về chẩn đoán và điều trị suy tim mạn: Cẩp nhât 2018. 2018.

5. Sulistiowati E, Sihombing M. NCEP-ATP III and IDF criteria for metabolic syndrome predict type 2 diabetes mellitus. Universa Medicina. 2016;35(1).

6. Bytyci I, Bajraktari G. Left atrial changes in early stages of heart failure with preserved ejection fraction. Echocardiography. 2016;33(10).

7. Berisha G, Bajraktari G, Ibrahimi P, Bytyçi I, Rexhepaj N, Elezi S, et al. Impaired Left Atrial Reservoir Function in Metabolic Syndrome Predicts Symptoms in HFpEF Patients. International Cardiovascular Forum Journal. 2015;4.

\title{
PHÂN TÍCH MỘT SỐ YẾU TỐ LIÊN QUAN ĐẾN CHỈ ĐINHH ĐĂT NộI KHÍ QUẢN Ở BỆNH NHÂN NHỒI MÁU NÃO DIỆN RộNG BÁN CẦU
}

\section{TÓM TẮT}

Mục tiêu: Phân tích một số yếu tố liên quan giữa đặc điểm lâm sàng, hình ảnh học và chỉ định đặt nội khí quản (NKQ) ở bệnh nhân nhồi máu não diện rộng

\section{${ }^{1}$ Bênh viện Bach Mai}

2Trường Đai học Y Hà Nọi

${ }^{3}$ Bênh Viên Đa khoa Của Đông.

Chịu trách nhiệm chính: Võ Hồng Khôi

Email: drvohongkhoi@yahoo.com.vn

Ngày nhận bài: 10.9.2021

Ngày phản biên khoa hoc: 15.10.2021

Ngày duyệt bài: 11.11.2021

\section{Võ Hồng Khôii ${ }^{1,2}$, Nguyễn Văn Quân ${ }^{3}$}

bán cầu. Đối tượng nghiên cứu: 69 bệnh nhân nhồi máu não diện rộng bán cầu, trong đó 38 bệnh nhân không đăt NKQ, 31 bệnh nhân có đặt NKQ điêu trị tại Trung tầm thần kinh Bệnh viện Bạch Mai từ tháng 8/2020-7/2021. Phương pháp nghiên cứu: Mô tả cắt ngang. Kết quả: Tuổi trung bình của nhóm bênh nhân nghiên cứu là $68,41 \pm 11,65$ tuổi, nam giới chiếm $60,9 \%$. Các triệu chứng lâm sàng khi khởi phát thường gặp là: liệt vận động $(100 \%)$, RL ngôn ngũ $(97,1 \%)$, đau đầu $(30,4 \%)$, buồn nôn/nôn $(30,4 \%)$, rối loạn ý thức $(60,9 \%)$, quay mắt quay đầu $(46,4 \%)$, rối loạn cơ tròn $(47,8 \%)$. Điểm NIHSS trung bình khi nhập viện là 19,0 $\pm 3,84$ điểm, điểm Glasgow trung bình lúc nhập viện là 12,9 $\pm 1,36$ điểm. Điểm ASPECT 
lúc nhập viện là 4,59 $\pm 1,01$ điểm; mức độ đè đẩy đường giữa trung bình là $4,48 \pm 3,97 \mathrm{~mm}$; có $24,6 \%$ bệnh nhân có chuyển dạng chảy máu. Các yếu tố liên quan độc lập đến chỉ định đặt NKQ có ý nghĩa thống kê bao gồm: RL ý thức lúc khởi phát (OR: 20,83, $95 \% \mathrm{CI}: 1,18-36,78)$, quay mắt quay đâu (OR: 4,41 , $95 \% \mathrm{CI}: 1,34-14,49)$, điểm NIHSS lúc vào viện $\geq 20$ điểm (OR: 39,48, 95\%CI: 1,63-95,53), di lệch đường giữa $\geq 5$ mm (OR: 13,65, 95\%CI: 2,10 - 88,90). Kết luận: Nhồi máu não diện rộng bán câuu là một dạng nặng của đột quy nhồi máu não với tỉ lệ tàn tật nặng và tữ vong cao. Các yếu tố có liên quan độc lập đến chỉ định đặt NKQ ở bệnh nhân nhồi máu não diện rộng bán cầu bao gồm: RL ý thức lúc khởi phát, quay mắt quay đầu, điếm NIHSS lúc vào viện $\geq 20$ điểm, di lệch đường giứa $\geq 5 \mathrm{~mm}$.

Tư khóa: Nhồi máu não diện rộng bán cầu, nội khí quản.

\section{SUMMARY \\ ANALYSIS OF SOME FACTORS RELATED TO INDICATION FOR INTUBATION OF LARGE HEMISPHERICAL INFARCTION PATIENTS}

Background: Analysis of some factors among clinical features, images and indication for intubation of large cerebral infarction patients. Objectives: Study of 69 patients with acute large hemispheric infarction, of which 38 patients without the intubation and 31 patients with the intubation, were treated in Neurological Center of Bach Mai Hospital from August 2020 to July 2021. Method: Cross-sectional descriptive study. Result: The average age of patients was 68,41 $\pm 11,65$, the percentage of male was $60.9 \%$. Frequent clinical symptoms onset included: paralysis $(100 \%)$, language disorder (97.1\%), headache (30.4\%), nausea/vomiting (30.4\%), consciousness disorder $(60.9 \%)$, head-eye deviation (46.4\%), urinary and fecal incontinence (47.8\%). The mean of NIHSS score, Glasgow score and ASPECT score at hospital admission

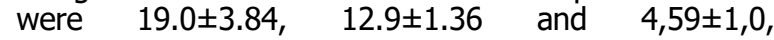
resprectively. The dregree of midline shift was $4,48 \pm$ $3,97 \mathrm{~mm}$, hemorrhagic transformation patients accounted for $24.6 \%$. Factors related to indication for intubation with statistical significance included: consciousness disorder at onset (OR: 20.83 , 95\% CI: 1.18 - 36.78), head-eye deviation (OR: $4.41,95 \% \mathrm{CI}$ : $1.34-14.49)$, NIHSS score at hospital admission $\geq 20$ points (OR: $39.48,95 \% \mathrm{CI}: 1.63-95.53)$, displacement midline $\geq 5 \mathrm{~mm}$ (OR: 13.65 , 95\% CI: 2.10 - 88.90). Conclusion: Large hemispherical infarction is a severe form of stroke with high morbidity and mortality. Factors related to indication for intubation at hemispherical infarction patients included: consciousness disorder at onset, head-eye deviation, NIHSS score at hospital admission $\geq 20$ points, midline shift classification $\geq 5 \mathrm{~mm}$.

Keywords: Large hemispherical infarction, intubation

\section{I. ĐẶT VẤN ĐỀ}

Nhồi máu não diện rộng bán cầu là một dạng nặng của đột quỵ nhồi máu não với hởn $50 \%$ bệnh nhân sẽ tiến triển thành phù não ác tính và suy giảm tình trạng thần kinh nhanh chóng trong vòng $2-3$ ngày từ khi khởi phát ${ }^{1}$. Tỷ lệ tử vong ở bệnh nhân nhồi máu não diện rộng bán cầu có phù não ác tính mặc dù đã được điều trị tích cực còn cao $(40-80 \%)^{1}$. Bệnh nhần nhồi máu nã̃o diện rộng bán cầu với diện tổn thương lớn, lâm sàng thường nặng nề, có thể kèm theo rối loạn ý thức, mất khả năng bảo vệ đường thở, ùn tắc đờm dãi hoặc suy hô hấp do ảnh hưởng trung khu hô hấp hay do các bệnh lý tim phổi. Việc đặt nội khí quản cho những bệnh nhân này là rất cần thiết để hổ trợ hô hấp, bảo vệ đường thở, đảm bảo cung cấp oxy đầy đủ cho tế bào não, góp phần chống phù não. Mặc dù tỉ lệ bệnh nhân nhồi máu não phải đặt NKQ không cao (10-16\%) nhưng tiên lượng xấu, di chứng thần kinh nặng nề, tî lệ tử vong cao (40-70\%) ${ }^{2}$. Việc xác định các yếu tố có liên quan đến chỉ định đặt nội khí quản ở những bệnh nhân nhồi máu não diện rộng bán cầu là cần thiết trong thực hành lâm sàng, cung cấp thêm các thông tin giúp các bác sĩ tiên lượng, theo dõi bệnh nhân trong quá trình điều trị. Xuất phát từ thực tế đó, chúng tôi tiến hành nghiên cứu đề tài này với mục tiêu: "Phân tích một số yêu tố liên quan đến chi định đặt nội khí quản ở bệnh nhân nhồi máu não diện rộng bán cầu".

\section{II. ĐỐI TƯƠNGG VÀ PHƯƠNG PHÁP NGHIÊN CỨU \\ 2.1 Đối tượng nghiên cứu}

- Các bệnh nhân được chẩn đoán nhồi máu não diện rộng bán cầu điều trị tại Trung tâm Thần kinh-Bệnh viện Bạch Mai từ 8/2020-7/2021.

\section{- Tiêu chuấn chọn bệnh nhân:}

+ Được chẩn đoán xác định nhồi máu não:

- Lâm sàng (theo định nghĩa đột quy. não của Tổ chức Y tế Thế giới 1990).

- Hình ảnh học: có hình ảnh nhồi máu não tương ứng trên CLVT/MRI.

+ Hình ảnh tổn thương nhồi máu não diện rộng trên CLVT/MRI: ASPECT < 6 điểm và có ít nhất một tổn thương hạch nền.

- Tiểu chuẩn loại trừ: tiền sử đột quỵ não có mRS $>2$ điểm hay có các bệnh lý nội khoa nặng như suy gan, suy thận nặng, ung thư', COPD...

\subsection{Phương pháp nghiên cứu}

- Thiết kế nghiên cứu: Nghiên cứu mô tả cắt ngang

- Tất cả các bệnh nhân khám thấy các dấu hiệu của đột quy não được chụp CT Scaner hoặc MRI sọ não để chẩn đoán xác định nhồi máu nã்o diện rộng bán cầu, sau đó được khai thác các triệu chứng lâm sàng và hình ảnh học theo một mẩu bệnh án thống nhất, theo dõi trong quá 
trình điều trị.

- Nội dung nghiên cứu:

+ Mồ tả các đặc điểm chung, đặc điểm lâm sàng, hình ảnh học ở bệnh nhân nhồi máu não diện rộng bán cầu.

+Phân tích một số yếu tố liên quan đến chỉ định đặt NKQ ở bệnh nhân nhồi máu não diện rộng bán cầu.

- Xử lý số liệu: theo phương pháp thống kê y học, sử dụng phần mềm SPSS 20.

\section{KẾT QUẢ NGHIÊN CỨU}

\section{1 Đặc điểm chung nhóm nghiên cứu} cứu

Bảng 3.1 Đặc điểm chung nhóm nghiên

\begin{tabular}{|l|c|c|c|}
\hline \multicolumn{2}{|c|}{ Đặc điếm chung } & Số bệnh nhân & Tỷ lệ(\%) \\
\hline \multirow{2}{*}{ Giới tính } & Nam & 42 & 60,9 \\
\cline { 2 - 4 } & Nữ & 27 & 39,1 \\
\hline \multicolumn{2}{|c|}{ Tuối trung bình } & \multicolumn{2}{|c|}{$68,41 \pm 11,65$} \\
\hline
\end{tabular}

Nhận xét: tuối trung bình của nhóm nghiên cứu là 68,41 tuổi. Giới nam chiếm đa số với 60,9\%.

3.2 Đặc điểm lâm sàng và hình ảnh học nhóm nghiên cứu

Bảng 3.2 Mốt số đặc điểm lâm sàng nhóm nghiên cứu

\begin{tabular}{|c|c|c|}
\hline Đặc điểm lâm sàng & $\begin{array}{c}\text { Số bệnh } \\
\text { nhẩn }\end{array}$ & $\begin{array}{c}\text { Tỷ lệ } \\
(\mathbf{\%})\end{array}$ \\
\hline Đau đâuu lúc khởi phát & 21 & $30,4 \%$ \\
\hline Buô̂n nôn/nôn lúc khởi phát & 21 & $30,4 \%$ \\
\hline Rối loạn ý thức lúc khởi phát & 42 & $60,9 \%$ \\
\hline
\end{tabular}

\begin{tabular}{|c|c|c|c|}
\hline \multicolumn{2}{|c|}{ Rôii loan cơ tròn lúc khởi phát } & 33 & $47,8 \%$ \\
\hline \multicolumn{2}{|c|}{ Quay mắt quay đầu } & 32 & $46,4 \%$ \\
\hline \multicolumn{2}{|c|}{ Rối loan nqôn ngữ } & 67 & $97,1 \%$ \\
\hline \multicolumn{2}{|c|}{ Liệt vận động } & 69 & $100 \%$ \\
\hline \multicolumn{2}{|c|}{ Điểm Glasgow lúc vào viện } & \multicolumn{2}{|c|}{$12,9 \pm 1,36$} \\
\hline \multicolumn{2}{|c|}{ Điểm NIHSS lúc vào viện } & \multirow{2}{*}{\multicolumn{2}{|c|}{$\begin{array}{l}19,0 \pm 3,84 \\
062 \pm 0,75\end{array}$}} \\
\hline \multirow{2}{*}{$\begin{array}{l}\text { Sức cơ } \\
\text { trung bình }\end{array}$} & Sức cơ tay & & \\
\hline & Sức cơ chân & \multicolumn{2}{|c|}{$0,77 \pm 0,84$} \\
\hline
\end{tabular}

Nhân xét: Triêu chứng lâm sàng nhồi máu não diện rộng bán câuu rất đa dạng, các triệu chứng thường gặp trong nhóm nghiên cứu là: liệt vận động $(100 \%)$, rối loạn ngôn ngữ $(97,1 \%)$, rối loạn ý thức lúc khởi phát $(60,9 \%)$. Điểm Glasgow trung bình lúc vào viện là 12,9 \pm 1,36 điểm, điểm NIHSS trung bình lúc vào viện là $19,0 \pm 3,84$ điểm.

Bảng 3.3 Đặc điểm hình ảnh học nhóm nghiên cứu

\begin{tabular}{|c|c|c|c|}
\hline \multicolumn{2}{|c|}{ Đặc điểm hình ảnh học } & $\begin{array}{c}\text { Số bệnh } \\
\text { nhẩn }\end{array}$ & $\begin{array}{c}\text { Tỷ lệ } \\
\mathbf{( \% )}\end{array}$ \\
\hline $\begin{array}{c}\text { Chuyến dạng } \\
\text { chảy máu }\end{array}$ & Kó & 17 & $24,6 \%$ \\
\cline { 2 - 4 } & Không & 52 & $75,4 \%$ \\
\hline \multicolumn{2}{|c|}{ Điếm ASPECT trung bình } & $4,59 \pm 1,01$ \\
\hline \multicolumn{2}{|c|}{ Mức độ di lệch đường giữa } & $4,48 \pm 3,97$ \\
\hline
\end{tabular}

Nhần xét: Có $24,6 \%$ bệnh nhân có chuyển dạng chảy máu trên hình ảnh học, điểm ASPECT trung bình lúc vào viện là $4,59 \pm 1,01$ điểm, mức độ di lệch đường giữa trung bình là $4,48 \pm$ $3,97 \mathrm{~mm}$.

3.3 Một số yếu tố liên quan giữa đặc điểm lâm sàng, hình ảnh học với chỉ định đặt NKQ Bảng 3.4 Liên quan giữa một số đặc điểm lâm sàng, hình ảnh học và chỉ định đặt NKQ

\begin{tabular}{|c|c|c|c|c|c|c|}
\hline \multirow{2}{*}{\multicolumn{2}{|c|}{ Đặc điểm lâm sàng }} & \multicolumn{2}{|c|}{ Không đặt NKQ } & \multicolumn{2}{|c|}{ Có đặt NKQ } & \multirow{2}{*}{$\mathbf{p}$} \\
\hline & & Số BN & Tỷ lệ (\%) & Số BN & Tỷ lệ (\%) & \\
\hline \multicolumn{2}{|c|}{ Đau đâu lúc khởi phát } & 6 & $15,8 \%$ & 15 & $48,1 \%$ & 0,008 \\
\hline \multicolumn{2}{|c|}{ Buốn nôn/nôn lúc khởi phát } & 7 & $18,4 \%$ & 14 & $45,2 \%$ & 0,032 \\
\hline \multicolumn{2}{|c|}{ RL ý thức lúc khởi phát } & 14 & $36,8 \%$ & 28 & $90,3 \%$ & $<0,001$ \\
\hline \multicolumn{2}{|c|}{ RL ngôn ngữ lúc khởi phát } & 36 & $94,4 \%$ & 31 & $100 \%$ & $>0,05$ \\
\hline \multicolumn{2}{|c|}{ RL cơ tròn lúc khởi phát } & 10 & $26,3 \%$ & 23 & $74,2 \%$ & $<0,001$ \\
\hline \multicolumn{2}{|c|}{ Quay mắt quay đầu } & 8 & $21,4 \%$ & 24 & $77,4 \%$ & $<0,001$ \\
\hline \multicolumn{2}{|c|}{ Điếm Glasgow lúc vào viện } & \multicolumn{2}{|c|}{$13,74 \pm 0,86$} & \multicolumn{2}{|c|}{$11,87 \pm 1,15$} & $<0,001$ \\
\hline \multicolumn{2}{|c|}{ Điểm NIHSS lúc vào viện } & \multicolumn{2}{|c|}{$16,68 \pm 2,23$} & \multicolumn{2}{|c|}{$21,81 \pm 3,53$} & $<0,001$ \\
\hline \multirow{2}{*}{$\begin{array}{l}\text { Sức cơ } \\
\text { trung bình }\end{array}$} & Sức cơ tay & \multirow{2}{*}{\multicolumn{2}{|c|}{$0,95 \pm 0,77$}} & \multicolumn{2}{|c|}{$0,23 \pm 0,50$} & $<0,001$ \\
\hline & Sức cơ chân & & & \multicolumn{2}{|c|}{$0,39 \pm 0,67$} & $<0,001$ \\
\hline \multicolumn{2}{|c|}{ Điếm ASPECT trung bình } & \multicolumn{2}{|c|}{$\begin{array}{l}1,08 \pm 0,85 \\
4,76 \pm 0,97\end{array}$} & \multicolumn{2}{|c|}{$4,39 \pm 1,15$} & $>0,05$ \\
\hline \multirow{2}{*}{\multicolumn{2}{|c|}{$\begin{array}{l}\text { Di lệch đường giữa } \\
\text { Chuyển dang chảy máu }\end{array}$}} & \multicolumn{2}{|c|}{$2,39 \pm 2,68$} & \multicolumn{2}{|c|}{$7,03 \pm 3,83$} & 0.001 \\
\hline & & & $7,9 \%$ & 14 & $45,2 \%$ & 0,001 \\
\hline
\end{tabular}

Nhận xét: Các triệu chứng lâm sàng có liên quan đến chỉ định đặt NKQ có ý nghĩa thống kê bao gồm: Đau đâuu lúc khởi phát, buồn nôn/nôn lúc khởi phát, RL ý thức lúc khởi phát, RL cơ tròn lúc khởi phát, quay mắt quay đầu, điểm Glasgow lúc vào viện, điểm NIHSS lúc vào viện, sức cơ trung bình lúc vào viện; với $p<0,05$. Di lệch đường giữa và chuyển dạng chảy máu trên hình ảnh học là hai yễu tố có liên quan đến chỉ định đắt NKQ với $p=0,001$.

Bảng 3.5 Một số yêuu tố liên quan đến chỉ định đặt NKQ trong phân tích hồi quy 
Logistic đơn biến

\begin{tabular}{|c|c|c|c|}
\hline Yếu tố liên quan & OR & $\mathbf{9 5 \%}$ CI & P \\
\hline Đauu đầu lúc khởi phát & 5,00 & $1,63-15,34$ & $\mathbf{0 , 0 0 5}$ \\
\hline Buồn nôn/nôn lúc khởi phát & 3,65 & $1,24-10,77$ & $\mathbf{0 , 0 1 9}$ \\
\hline RL ý thức lúc khởi phát & 16,00 & $4,10-62.40$ & $<\mathbf{0 , 0 0 1}$ \\
\hline RL cơ tròn lúc khởi phát & 8,05 & $2,73-23,73$ & $<\mathbf{0 , 0 0 1}$ \\
\hline Quay mắt quay đầu & 12,86 & $4,08-40,51$ & $<\mathbf{0 , 0 0 1}$ \\
\hline Glasgow vào viện $\leq 12$ điếm & 28,50 & $5,77-140,71$ & $<\mathbf{0 , 0 0 1}$ \\
\hline NIHSS vào viện $\geq 20$ điểm & 16,13 & $4,77-54,60$ & $<\mathbf{0 , 0 0 1}$ \\
\hline Di lệch đường giữa $\geq 5 \mathrm{~mm}$ & 5,86 & $2,05-16,73$ & $\mathbf{0 , 0 0 1}$ \\
\hline Chuyến dạng chảy máu & 9,61 & $2,43-38,00$ & $\mathbf{0 , 0 0 1}$ \\
\hline
\end{tabular}

Nhận xét: Các yếu tố trong bảng đều có liên quan đến chỉ định đặt NKQ có ý nghĩa thống kê trong phân tích đơn biến với $\mathrm{p}<0,05$.

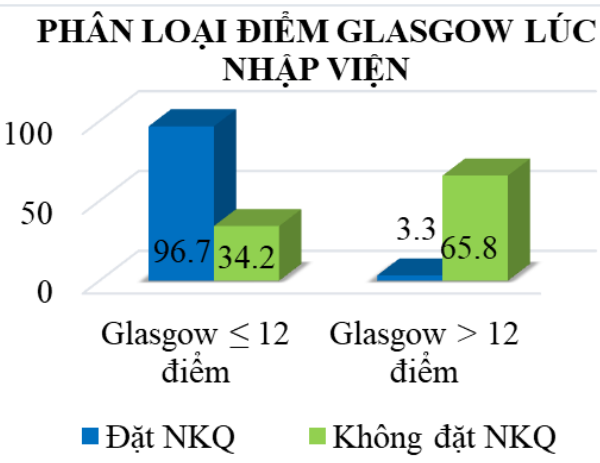

\section{Biểu đồ 3.1: Phân loại điểm Glasgow lúc nhập viện}

Nhận xét: Có $96,7 \%$ bệnh nhân có rối loạn ý thức mức độ vừa và nặng (Glasgow $\leq 12$ điểm) lúc vào viện có chỉ định đặt NKQ, trong khi ở nhóm không đă̆t NKQ tỷ lệ là 34,2\%.

Bảng 3.6 Một số yếu tố liên quan đến chi định đặt NKQ trong phân tích hồi quy Logistic đa biến

\begin{tabular}{|c|c|c|c|}
\hline Yếu tố liến quan & OR & $\mathbf{9 5 \%} \mathbf{~ C I}$ & $\mathbf{P}$ \\
\hline $\begin{array}{c}\text { Rối loạn ý thức lúc } \\
\text { khởi phát }\end{array}$ & 20,83 & $\begin{array}{c}1,18- \\
36,78\end{array}$ & 0,043 \\
\hline $\begin{array}{c}\text { Quay mắt quay } \\
\text { đâuu }\end{array}$ & 4,41 & $\begin{array}{c}1,34- \\
14,49\end{array}$ & 0,034 \\
\hline $\begin{array}{c}\text { NIHSS vào viện } \geq \\
20 \text { điể }\end{array}$ & 39,48 & $\begin{array}{c}1,63- \\
95,53\end{array}$ & 0,024 \\
\hline $\begin{array}{c}\text { Di lệch đường } \\
\text { giữa } \geq 5 \mathrm{~mm}\end{array}$ & 13,65 & $\begin{array}{c}2,10- \\
88,90\end{array}$ & 0,021 \\
\hline
\end{tabular}

Nhận xét: Trong phân tích hồ quy Logistic đa biến, các yếu tố có liên quan đến chỉ định đặt NKQ có ý nghĩa thống kê (với $p<0,05)$ bao gồm: RL ý thức lúc khởi phát, quay mắt quay đầu, điểm NIHSS lúc vào viện $\geq 20$ điểm và di lệch đường giữa $\geq 5 \mathrm{~mm}$.

\section{BÀN LUÂ̂N}

Tuổi trung bình ở nhóm bệnh nhân nghiên cứu là $68,41 \pm 11,65$ tuổi, cao hớn kết quả nghiên cứu của Santoli và cộng sự $(65 \pm 13 \text { tuổi })^{3}$ và nghiên cứu của Popat và cộng sự $(60,3 \pm 14,3)^{4}$. Nam giới chiếm phần lớn với $60,9 \%$ cao hơn kết quả nghiên cứu của Schielke và cộng sự (nam giới chiếm $55,4 \%)^{5}$.

Triệu chứng lâm sàng ở bệnh nhân nhồi máu não diện rộng bán cầu rất đa dạng, trong nghiên cứu của chúng tôi, các triệu chứng lâm sàng lúc khởi phát thường gặp bao gồm: liệt vận động $(100 \%)$, RL ngôn ngữ $(97,1 \%)$, RL ý thức $(60,9 \%), \mathrm{RL}$ cơ tròn $(47,8 \%)$, đau đâu $(30,4 \%)$, buồn nôn/nôn (30,4\%). Điểm Glasgow lúc nhâp viện là $12,9 \pm 1,36$ điểm, trong đó có $96,7 \%$ bệnh nhân có điểm Glasgow $\leq 12$ điểm có chỉ định đặt NKQ. Điểm NIHSS lúc vào viện là 19,0 $\pm 3,84$ điểm. Walcot và cộng sự nghiên cứu 46 bệnh nhân nhồi máu não do tắc động mạch não giữa nghiêm trọng nhận thấy điểm Glasgow lúc vào viện là $10,7 \pm 0,4$ điểm, điểm NIHSS lúc vào viện là $20,9 \pm 0,5$ điểm ${ }^{6}$.

Kết quả nghiên cứu của chúng tôi cho thấy, các yếu tố lâm sàng có liên quan đến chỉ định đă̆t NKQ trong phân tích hồi quy Logistic đơn biến và đa biến bao gồm: RL ý thức lúc khởi phát (OR: 20,83, 95\%CI: $1,18-36,78, p=0,043$ ), quay mắt quay đầu (OR: $4,41,95 \% \mathrm{CI}: 1,34-$ $14,49, p=0,034)$, điểm NIHSS lúc vào viện $\geq 20$ điểm (OR: 39,48, 95\%CI: 1,63-95,53, p= $0,024)$. Nhận định này của chúng tôi có khác so với các kết quả nghiên cứu của Gupta và Nguyễn Thị Oanh đều cho thấy RL ý thức lúc khởi phát là yếu tố có liên quan đến chỉ định đặt NKQ với $p<$ 0,05 , nhưng quay mắt quay đầu và điểm NIHSS lúc vào viện $\geq 20$ điểm không liên quan đến chỉ định đặt NKQ với $p>0,05^{2,7}$.

Điểm ASPECT trung bình lúc nhập viện ở nhóm bệnh nhân nghiên cứu là 4,59 $\pm 1,01$ điểm, mức độ di lệch đường giữa trung bình trên hình ảnh học là $4,48 \pm 3,97 \mathrm{~mm}$. Chuyển dạng chảy máu chiếm $24,6 \%$ và là yếu tố có liên quan 
đến chỉ định đă̆t NKQ trong phân tích đơn biến (OR: 9,61,95\%CI: $2,43-38,00, p=0,001$ ). Di lệch đường giữa $\geq 5 \mathrm{~mm}$ là yếu tố có liên quan đến chỉ định đặt NKQ trong phân tích đa biến (OR: 13,65 , 95\%CI: $2,10-88,90, p=0,021$ ). Kết quả này tương tự kết quả nghiên cứu của Nguyễn Thị Oanh khi cho rằng đè đẩy đường giữa độ 2 trở lên là yếu tố liên quan chặt chẽ với chỉ định đặt NKQ với $p<0,001^{7}$.

\section{KẾT LUÂN}

Nhồi máu não diện rộng bán câu là một dạng nặng của đột quy nhồi máu não với tỉ lệ tàn tật nẳng và tử vong cao. Các yếu tố có liên quan độc lập đến chỉ định đặt NKQ ở bệnh nhân nhồi máu não diện rộng bán cầu có ý nghĩa thống kê với $\mathrm{p}>0,05$ bao gồm: RL ý thức lúc khởi phát (OR: 20,83, 95\%CI: $1,18-36,78$ ), quay mắt quay đầu (OR: 4,41,95\%CI: $1,34-14,49$ ), điểm NIHSS lúc vào viện $\geq 20$ điểm (OR: 39,48 , $95 \%$ CI: 1,63 - 95,53), di lệch đường giữa $\geq$ $5 \mathrm{~mm}$ (OR: $13,65,95 \%$ CI: $2,10-88,90$ ).

TÀI LIỆU THAM KHẢO

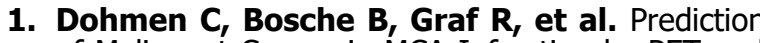
of Malignant Course in MCA Infarction by PET and Microdialysis. Stroke. Published online September $1,2003$.

2. Gupta P, Prasad K, Kumar A, Kumar P, Bhatia $\mathbf{R}$, Tripathi M. Clinical predictors and outcome of patients of acute stroke requiring ventilatory support: A prospective hospital based cohort study. Journal of the Neurological Sciences. 2014;337(1-2):14-17.

3. Santoli F, De Jonghe B, Hayon J, et al. Mechanical ventilation in patients with acute ischemic stroke: survival and outcome at one year. Intensive Care Med. 2001;27(7):1141-1146.

4. Popat C. Outcomes in patients with acute stroke requiring mechanical ventilation_Predictors of mortality and successful extubation. $2018: 19$.

5. Schielke E, Busch MA, Hildenhagen $T$, et al. Functional, cognitive and emotional long-term outcome of patients with ischemic stroke requiring mechanical ventilation. J Neurol. 2005;252(6):648-654.

6. Walcott BP, Miller JC, Kwon C-S, et al. Outcomes in Severe Middle Cerebral Artery Ischemic Stroke. Neurocrit Care. 2014;21(1):20-26.

7. Oanh TT. Nghiên cứu đặc điểm lâm sàng, cận lâm sàng và một số yếu tố liên quan của bệnh nhân nhồi máu nã̃o cấp trên lều tiểu não có thông khí cơ học. $2018: 27$.

\section{LIỆU PHÁP TẾ BÀO GỐC TRONG ĐIỀU TRI CHẤN THƯƠ'NG CHİNH HÌNH}

\section{TÓM TẮT}

Ứng dụng hứa hen nhất của tế bào gốc xuất phát từ chính khả năng biến đổi thành nhiều loại tế bào trưởng thành khác nhau với đầy đủ chức năng. Tế bào gốc chính là nguồn tiềm năng cho việc thay thế các tế bào nhằm điều trị nhiều chứng bệnh. Trong bài viết này, tác giả giới thiệu vắn tắt một số đă̆c điểm về tế bào gốc, nguî̀n thu gom tế bào gốc, các loại tế bào gốc có thể sử dung trong chấn thương chỉnh hình. Một số bệnh lý trong chấn thương chỉnh hình có thể điều trị bẳng công nghê tế bào gốc

Tư khoá: Tế bào gốc, chấn thương chỉnh hình, y học tái tạo

\section{SUMMARY}

\section{STEM CELL THERAPIES} IN ORTHOPAEDIC TRAUMA

The most promising application of stem cells

${ }^{1}$ Dại Học Y Hà Nội

${ }^{2}$ Bênh viện HN Viêt Đức

Chịu trách nhiệm chính: Dương Đình Toàn

Email: duongdinhtoan@hmu.edu.com

Ngày nhận bài: 6.9.2021

Ngày phản biên khoa họ: 29.10.2021

Ngày duyệt bài: 8.11.2021

\section{Dương Đình Toàn ${ }^{1,2}$, Nguyễn Đình Hoà ${ }^{2}$}

comes from their ability to transform into many different types of fully functional adult cells. Stem cells are a potential source for replacing cells to treat many diseases. In this article, the author briefly introduces some characteristics of stem cells, stem cell collection sources, and types of stem cells that can be used in orthopedic. Some diseases in orthopedic can be treated with stem cell technology

Keywords: Stem cells, orthopedic, regenerative medicine

\section{I. ĐĂT VẤN ĐỀ}

Tế bào gốc (stem cell) đang được cộng đồng xã hôi và các nhà khoa học quan tâm đặc biêtt. Với niềm hi vọng to lớn, đông đảo công chúng đang dõi theo những kết quả mà các nhà khoa học trong và ngoài nước đã đạt được trong lĩnh vực nghiên cứu, ứng dụng tế bào gốc.

Tế bào gốc là những tế bào không (hoăc chưa) chuyên hóa trong mô sống, chúng có khả năng trở thành các tế bào chuyên hóa với các chức phân sinh lí. Trong điều kiên in vivo hay in vitro, mổi tế bào gốc có thể tự làm mới với các tính năng riêng biệt mới. Chẳng hạn các tế bào gốc tủy xương hoàn toàn chưa được chuyên hóa, 